\title{
A percepção da comunicação digital entre bibliotecários escolares: a integração social em um momento de pandemia
}

The perception of digital communication among school libraries: social integration in a time of pandemic

\author{
Rosa da Penha Ferreira da Costaa \\ Marcelo Calderari Miguel ${ }^{b, *}$ (i) \\ Sandra Maria Souza De Carvalhoc ${ }^{\mathbb{B}}$
}

RESUMO: Esta pesquisa busca reconhecer as perspectivas e desafios informacionais em tempos de pandemia da Covid-19. Como procedimento metodológico foi aplicado um questionário não estruturado direcionado por e-mails e WhatsApp ${ }^{\mathrm{TM}}$ aos bibliotecários escolares do município de Vila Velha, localizado no estado do Espírito Santo. Os respondentes apontam inovações no cenário digital e sinalizam que as novas tecnologias permitem acontecer e avançar a integração social - o cerne da questão envolve transformações e provocações para o 'adaptar' profissional. Ressalta-se ainda a importância das organizações capacitar seus colaboradores e, se percebe, que a internet, se bem conduzida, traz benefícios para toda a comunidade interna e externa.

Palavras-chave: Comunicação Digital; COVID-19; SARS-CoV-2; Bibliotecário Escolar; Tecnologia Digital.

ABSTRACT: Research seeks to recognize informational perspectives and challenges in times of the Covid19 pandemic. As a methodological procedure, an unstructured questionnaire is applied to emails and WhatsApp ${ }^{\mathrm{TM}}$ from school librarians in Vila Velha City, Brazil. Respondents point to innovations in the digital landscape and signal that new technologies make things happen and advance social integration. The core involves transformations and provocations to adapt it professionally. It is emphasized the importance of organizations to train their employees and, if they realize, that the internet, if well conducted, brings benefits to the entire internal and external community.

Keywords: Digital Communication; COVID-19; SARS-CoV-2; School Librarian; Digital Technology.

\footnotetext{
a Programa de Pós-Graduação em Ciência da Informação, Universidade Federal do Espírito Santo, Vitória, ES, Brasil.

b Centro De Ciências Jurídicas e Econômicas, Universidade Federal do Espírito Santo, Vitória, ES, Brasil.

c Prefeitura Municipal de Vila Velha, Vila Velha, ES, Brasil.

* Correspondência para/Correspondence to: Marcelo Calderari Miguel. Endereço: Av. Fernando Ferrari, 514 Goiabeiras, CEP 29075-910, Vitória - ES, Brasil. E-mail: marcelocalderari@yahoo.com.br.

Recebido em/Received: 04/07/2020; Aprovado em/Approved: 04/11/2020.
}

Artigo publicado em acesso aberto sob licença CC BY 4.0 Internacional $($ )(i) 


\title{
PANDEMIA E UMA ERA DE PLURALIDADES, CONEXÕES E IMAGENS: DISSONÂNCIAS, DISTOPIAS E A VARIEDADE NO ATUAL CENÁRIO
}

\author{
Provisoriamente não cantaremos o amor, / que se refugiou mais \\ abaixo dos subterrâneos. / Cantaremos o medo, que esteriliza os \\ abraços, / não cantaremos o ódio porque esse não existe, / existe \\ apenas o medo, nosso pai e nosso companheiro, / o medo grande \\ dos sertões, dos mares, dos desertos, / o medo dos soldados, o \\ medo das mães, o medo das igrejas, / cantaremos o medo dos \\ ditadores, o medo dos democratas, / cantaremos o medo da morte \\ e o medo de depois da morte, / depois morreremos de medo / e \\ sobre nossos túmulos nascerão flores amarelas e medrosas \\ (ANDRADE, C. D., 1979, p. 108-109).
}

Reza a lenda que o mundo é feito de espantos. Outra lenda diz que em terras capixabas, dois indígenas de tribos diferentes se apaixonaram em plena guerra, tal amor foi duramente punido e o casal apartado foi transformado em duas grandes pedras (Mestre Álvaro na Serra e o Monte Mochuara em Cariacica). Esses dois rochedos apenas se olham (estão frente a frente), mas não se tocam; porém uma vez por ano (em noite de São João) um pássaro de fogo ilumina o céu levando mensagens de um para o outro (há quem diga que já viu o pássaro de fogo adejar).

E não muito longe da Grande Vitória, existe o Monumento natural conhecido como o Frade e a Freira; diz a lenda que há muitos anos um frade e uma freira se encontraram, e tamanha foi a cumplicidade entre os dois - e se insinua ali um afeto (paixão, amor) impossível de se viabilizar. Coube então o mistério para eternizar e transformar tal situação, assim, a natureza guardiã imortalizou o sofrimento e o sentimento desses personagens, e frente a frente foram transformados em pedra mostrando que o distanciamento é uma forma de salvar. Destarte, o folclore é riquíssimo e mostra como se lidar com os medos, nele se apresenta a constituição de arquétipos, uma vasta gama de estereótipos, um mundo de fantasias representativas e convidativas ao aprendizado. Há magia, monstros e encantos - além de dilatar os limites, entorno ou contorno.

Gerlin (2019, p. 7) assinala que as "lendas reproduzem desejos, esperanças e explicação de aspectos humanos e geográficos de uma determinada cultura, transformando fatos reais em ficção fortalecida pelo imaginário popular". Assim sendo, existe nas lendas elementos social e moral. Contudo, o entra e sai de panapaná e alcateias dá lugar a um novo agente - a estória cita o proliferar em avalanche, o um eclodir de um vulcão. Eis o mers e sars (Covid-19) trazendo à tona uma malfazeja maré - o coronavírus se torna um dos assuntos mais comentados, temidos e desafiador para as relações no mundo.

Assim, os estudos de Porto (2006) apontam que o ato de se comunicar vai além da oralidade, de gestos, abrangendo a arte de escrever e diálogos na conversação, pois este pode ser constituído também por meio de instrumentos e soluções contemporâneas de entendimento atualizado mundialmente, em peculiar, a internet. Para Porto (2006) "as ações socioculturais vão mudando ao longo do tempo em decorrência da influência das transformações tecnológicas em nossa sociedade e a internet tem grande impacto nessas mudanças", até mesmo nos relacionamentos, gerando grande influência nos aspectos psicológicos das pessoas (PORTO, 2006, p.50).

Mill (2018) declara que nas últimas décadas têm experimentado muitas transformações proporcionadas pelas tecnologias digitais como: mudanças culturais, sociais, educacionais, comunicacionais e tecnológicas. Essa nova era digital adequou transformações expressivas em toda a sociedade e, não obstante, diminuiu as distâncias, mudou conceitos, trouxe mobilidade, facilitou o acesso às informações e 
mudanças no comportamento humano como o modo de ser, agir, e se relacionar socialmente.

Diante do exposto, o objetivo principal do trabalho é analisar os impactos ocorridos diante a pandemia do Covid-19, com a utilização das ferramentas digitais na ambiência educacional. Seus objetivos específicos são: identificar as formas de comunicação vigentes na era digital, averiguar a reação da sociedade da informação frente às comunicações digitais e avaliar os fatores de impacto no uso dessas tecnologias diante o momento de pandemia.

A metodologia aborda a pesquisa exploratória, com um estudo de coleta e análise de informações, esclarecendo em detalhes a temática selecionada, com a entrevista em forma de questionário aplicado online a rede de bibliotecários do município de Vila Velha- ES. A abordagem é mista, e nela se adentra um tipo de investigação que aprecia aspectos intrassubjetivos traduzidos ou não em números.

\section{ADAPTAR SE APRENDE ADAPTANDO: DIÁLOGO, CONVÍVIO E RUMORES}

O conceito de diálogo é instituído por vários pesquisadores, que expõem suas contribuições sobre o tema. Nesse âmbito é pertinente observar que para Vieira (2016, p. 299) a assimilação social "interage com a tecnologia, isto é, como as pessoas usam, aperfeiçoam, exploram, adaptam, e, provavelmente, moldam a tecnologia ou são moldados por esta".

Assim entendido, é natural considerar nesse panorama, que todo o entendimento da humanidade possui uma determinada fonte, um indivíduo ou um grupo de pessoas com uma finalidade, um motivo para se empenhar em diálogos (BERLO, 1985). A ótica de Berlo (1985), citando Aristóteles, mostra que a comunicação é "o estudo da retórica como a procura de todos os meios disponíveis de persuasão", assim destaca - o objetivo principal da comunicação é a convicção, a experiência de levar outros indivíduos a adotarem o ponto de vista do interlocutor. Para o pesquisador, instituída a originalidade do ato de comunicar com conceitos, precisões, finalidades, conhecimentos e objetivos a dialogar, torna-se imprescindível o segundo elemento; assim, o objeto da fonte se expressa em formato de mensagem.

Nessa via de pesquisa, Tomaél (2007, p. 96) argumenta que:

Existem seis elementos no ato de comunicar: Mensagem - o conjunto de quem se destina a mensagem; o código - um sistema de signos que emissor e receptor informações que se quer transmitir; o emissor ou remetente - aquele de quem parte a mensagem; o receptor - aquele a precisam compartilhar, total ou parcialmente, para que haja a comunicação; o canal ou contato - o meio físico pelo qual emissor e receptor se comunicam referente ao contexto - o assunto da mensagem, aquilo a que ela se refere. Assim, o coletivo direciona práticas pensantes em prol das interações sociais e as formas de comunicação sofrem alterações com a evolução tecnológica.

De acordo com Freire (2009) o ato de compartilhar informações, pode ser analisado como um procedimento ativo subjacente à experiência, ao desenvolvimento, à transformação e à conduta de todos os sistemas vivos (indivíduo ou organização). Assim, a comunicação pode ser compreendida "nas interações indispensáveis ás pessoas e organizações, através da qual a organização ou o organismo se relacionam com o meio ambiente, com os outros e com suas próprias partes" (FREIRE, 2009, p.15) 
e as formas de comunicação sofrem alterações com a evolução tecnológica como será visto a seguir.

\section{O surgir da era digital: a infoera e o coletivo pensante online}

Lévy (1999, p. 31-32) destaca que no final dos anos 80 e no início dos anos 90, um "novo movimento sociocultural trazido por jovens profissionais de campi americanos e das grandes metrópoles tomou uma ligeira dimensão planetária". "Isto é, redes distintas de computadores se conectam umas às outras e uma interrede mundial começou a se expandir de formato exponencial". Portanto, as Tecnologias Digitais de Informações e Comunicações (TDICs), surgem para constituir uma infraestrutura de ciberespaço novo espaço de comunicar, de sociabilizar, de organizar e de transação, mas igualmente novo mercado da comunicação e do conhecimento.

Castells (2004, p. 89) ressalta que, na década de 1990, a capacidade de comunicação da internet junto com os novos procedimentos tecnológicos, gerou modificações tecnológicas drásticas. Destarte, a comunicação digital tece um conjunto de normas relacionadas com "o comportamento apropriado e responsável no uso das ferramentas tecnológicas e, portanto, a realidade social hodierna insere as pessoas em redes de relacionamento, tornando quase impossível viver em sociedade de modo offline" (CASTELLS, 2004, p. 300).

Começa uma alteração no modo de comunicação, que se desenvolverá cada vez mais, refletindo não apenas na forma como a sociedade se relaciona, mas que traz um novo modelo de sociedade. Barreto (1998) assevera que as mudanças "advindas pelas redes de tecnologias proporcionam um novo tipo de sociedade, a sociedade em rede, e definida como sociedade digital - lugar de convergências de ideias, percepção e memória" (BARRETO, 1998, p. 11).

Vieira (2016, p. 39) considera que a "popularização da comunicação digital, principalmente através da internet e da massificação de smartphones mais recentemente, tem gerado impactos relevantes na vida de cidadãos, grupos, organizações e governos, inserindo novos ingredientes nas práticas sociais" (VIEIRA, 2016, p. 39). Assim, nessa via de pesquisa observa-se que:

Enfim, não podemos nos prender aos conceitos e tecnologias somente da atualidade, temos que ter a plena noção e certeza que tudo irá evoluir. Pode-se dizer que este é um dos objetivos do ser humano: sempre procurar evoluir. É o que aconteceu desde o início da invenção do computador, da internet e das coisas, até chegar o momento em que as próprias máquinas se controlarão. A virtualização é uma realidade inegável. As pessoas conheceram o novo, aprenderam a utilizar e se acostumaram com a nova era. E é assim que será feito com os próximos passos dessa era digital, serão criadas novas tecnologias, as pessoas irão conhecer e se acostumar e o ciclo irá continuar (SILVA; FELIX, 2016, p. 32).

Para Silva e Felix (2016), as novas formas de trocas de informações trazem ainda mais transformações para a sociedade contemporânea. E dessa forma, a interações em mídias sociais (Twitter, Facebook, Instagram, Linkedln, Reddit, etc.) é a forma mais dinâmica e hábil, nessa via podemos, segundo esses autores, nos conectar usando diferentes tipos de dispositivos eletrônicos, tais como aparelhos de celular, TVs não ficando restritos ao uso apenas de computadores. 
O 'estar na rede' é ser participante ativo da nova era da humanidade, que é uma potência de comunicação social (PORTO, 2006). Destarte, como afirmam Tomaél, Alcará e Di Chiara "as interações que movimentam as redes são representadas por relações sociais, econômicas, de trabalho, que essencialmente, possibilitam o compartilhamento de informação e conhecimento" (TOMAÉL; ALCARÁ; DI CHIARA, 2005, p. 102).

A participação em rede permite formas de comunicação em diferentes níveis. Berlo (1985, p.11) ratifica, que "as pessoas podem comunicar-se em muitos níveis, por muitas razões, com muitas pessoas, de muitas formas". É possível acrescentar que o profissional bibliotecário desempenha um papel essencial para o capitalismo informacional, pois age na e com a matéria-prima para além do senso comum dos produsers (cidadãos que usam ou consomem informações de um ambiente online e também lançam informações para uso de terceiros).

Já Kanan e Arruda (2013) citam que os dispositivos de comunicação se tornaram um meio de vigilância, ou seja, possuem um poder sobre as pessoas, como por exemplo, o que elas fazem, deixam de fazer, do que gostam ou sentem. A facilidade da visibilidade total das coisas retirou certa privacidade e isso pode ocorrer problemas prejudiciais, pois muitas pessoas se expõem de forma inapropriada, e assim:

\begin{abstract}
As TICs são colaboradoras e organizadoras dessa nova paisagem do metabolismo do capital. A esfera digital é privatizada e disputada pelos atores privilegiados que a utilizam para manter sua dominação [...]. As infovias de comunicação e informação arquitetam a distribuição e circulação de valores e costumes e ganham espaço entre as maiorias sociais utilizando os diversos aparelhos privados de hegemonia em relevo em um dado contexto histórico. Aliás, percebe-se que a própria internet é um locus centralizador desses aparelhos ao tornar-se a "estrada" de diversas modalidades de relações sociais (SOUZA, p. 5-8, 2020).
\end{abstract}

Essa linha de raciocínio encontra-se subsídios em textos de Castells $(2004,2007)$ e em Habermas (2012); para esse último autor, as mudanças na forma de pensar tem gerado um novo tipo de pensamento que deve ser ágil, integrado e relativizado, já para Castells (2004, 2007), em relação aos fatores econômicos relacionados à internet, o referido autor concerne a elasticidade da internet e a torna particularmente suscetível a intensificar tendências contraditórias presentes em nosso mundo.

Tendo em vista ainda os argumentos do autor Castells (2004, p. 75) nem utopia nem distopia, a internet é "a expressão de nós mesmos através de um código de comunicação específico, que devemos compreender se quisermos mudar nossa realidade"; e assim, o autor afirma que a invenção da internet reforça também a "ideia de que a cooperação e a liberdade de informação" podem ser mais propícias à inovação do que a competição e os direitos de propriedade.

\title{
Bibliotecários Escolares E O Tecer De Uma Rede Em Face De Pandemia Covid- 19
}

Constata- se atualmente, a existência de estudos referentes ao desenvolvimento da biblioteca escolar como ambiência de aprendizagem. Assim para Bedin; Chagas e Sena (2016), existem algumas ações "governamentais que destacam a importância da biblioteca escolar, como por exemplo a Lei 12.244, de 2010, que exige a presença de 
bibliotecas e bibliotecários em instituições escolares públicas e privadas de todo o Brasil” (BEDIN ; CHAGAS ; SENA, 2016,p.21).

Embora esse projeto de Lei determinasse que a universalização das bibliotecas fossem efetivadas até maio de 2020, um outro Projeto de Lei 4401 de 2020, criada pela Deputada Professora Dayane Pimentel (PSL-BA) adia para o ano de 2022 o prazo para universalização de bibliotecas públicas e privadas, segundo argumentos da deputada, o adiamento se faz imprescindível em função da pandemia de Covid-19; e, a crise econômica - posto que a biblioteca escolar deve possuir um espaço físico acessível e adequado ao número de alunos. Outra mudança sugerida pela deputada Pimentel é o acervo mínimo de cada biblioteca escolar tenha "2.500 títulos, e um livro para cada aluno matriculado (SIQUEIRA, 2020, p.1)".

Santana Filho (2005) esclarece que a biblioteca escolar deve assumir o seu papel de incentivo à leitura reflexiva, pois é nessa ambiência que o aluno poderá desenvolver a compreensão do texto, repleto de significados e conhecimentos relevantes. Assim, a biblioteca escolar "saiu das quatro paredes, deixando de ser um castelo fechado em si mesmo e abrindo para a democratização, a construção do conhecimento, transformando-se em um amplo ambiente de aprendizagem" (MORO; ESTABEL, 2011, p.13).

Nessa perspectiva, os pesquisadores Fusatto e Silva (2014) consideram que a biblioteca escolar é um espaço que possui características próprias. Portanto, é necessário que proporcione recursos bibliográficos relacionados com o perfil de seus usuários, para que a aprendizagem se efetive.

Nessa linha de pesquisa, Aguiar (2012) reporta que a adaptação das crianças no contexto informacional do conhecimento, introduzidas pela era tecnológica que se encontra em constante evolução e transformações, requer além das habilidades tecnológicas, que essas crianças desenvolvam a identificação de conteúdo e a consciência crítica, diante dessa imensa abundância de conhecimentos, e a biblioteca escolar, com um profissional da informação dinâmico e atualizado, exercem um papel de grande relevância, pois é nessa ambiência que é disponibilizada a informação capaz de promover o processo de ensino aprendizagem nesse público infantil, não só para pesquisas escolares, mas para toda a sua vida.

Miguel e Carvalho (2019) salientam que "a biblioteca escolar transcorre por um campo a ser perspectivada, compreendendo uma ambiência social de encontros entre diversas gerações". Em suma, a ambiência da escola é um espaço que propicia e favorece não somente a compreensão dos fenômenos sociais e objetos culturais, mas também a formação e informação ao indivíduo desenvolvendo capacidades e fruição de objetos, assim, podem perceber a importância da presença de uma biblioteca dentro da escola (CARVALHO; MIGUEL; COSTA, 2020, p.7).

Já Chagas (2009) expõe que as bibliotecas escolares adquirem um papel de valor essencial por que sobrevirão a servir como intermediárias entre os leitores, as informações, e, por conseguinte, todos os dados ali apontados. A pesquisadora ainda observa que "o uso da internet como ferramenta de apoio aos processos de ensinoaprendizagem, é considerada como uma riqueza de informações e recursos disponíveis [...] além de outros recursos, que tornam a informação mais atrativa" (CHAGAS, 2009, p. 10).

Na visão de D'Ávila e Fachin (2016):

Uma biblioteca, em especial a escolar, acima de tudo, é um lugar libertador, pois nos livros residem os sonhos, utopias, medos, 
glórias, revoluções, enfim a sabedoria. A leitura permite a evolução do indivíduo, de forma que cada um desenvolva sua criticidade e participe efetivamente na construção da sociedade (D'AVILA; FACHIN, 2016, p.94).

A sociedade de informação vem se modificando, com as novas Tecnologias de Informação e Comunicação (TICs), em especial com ferramentas digitais conectadas á internet. Observamos a todo instante que esses avanços estão modificando o ambiente de aprendizagem, com isso faz-se imprescindível que as escolas e os bibliotecários estejam preparados e possuam uma posição essencial mediadora, que possa contribuir na preparação desse público infantil para o uso inteligente da informação disponível por meio das tecnologias, essencialmente nesse período pandêmico que estamos vivenciando, mesmo que esses avanços tecnológicos veem sendo considerados uma provocação para a escola e o bibliotecário, devido as várias fontes de conhecimentos disponíveis, tornou-se a principal ferramenta para o continuar da Educação a Distância (EaD), o reaprender a ensinar (KUHLTHAU,1999).

Nesse contexto, o Covid-19 impacta gravemente vários setores e, especialmente, a educação, acostumada a mudanças lentas e graduais. Tendo em vista esses elementos e vivenciando o avançar do coronavírus que, abala as noções sanitárias do planeta, e provoca novos insights a inesgotável capacidade criadora humana. Assim, em relação à prática da mediação pelo bibliotecário escolar, no "saber-fazer e a ação técnica e instrumental, é essencial que sejam dispostas pela ação comunicativa a qual conduz práticas discursivas e uso de habilidades linguísticas na interação dos sujeitos na biblioteca" (CASTRO; SILVA; OLIVEIRA, 2020, p. 295).

O 'novo normal' revela um contexto situacional de se repensar novas 'formas de viver, aprender e ensinar', apontando um cenário que ressalta o valor do lar e, que nem tudo está sobre controle - isso faz emergir novas formas de se reinventar, e esses "protagonistas" os profissionais da informação, em contato com a crise sanitária que abalou o mundo, tiveram que sair da caixa e aprender a usar novas tecnologias para dar continuidade ao trabalho de atendimento aos seus usuários. Essa sintonia no âmbito da informação fez ressignificar alguns projetos e novos projetos foram e continuam surgindo ainda, para promover o processo de ensino-aprendizagem nessa era de distanciamento físico e social, utilizando a conectividade das redes digitais de forma ética, já que com o enorme fluxo de informações acaba gerando muito fake news (notícias falsas).

É importante ressaltar que novos fazeres e saberes se fez presente no dia- a- dia do bibliotecário escolar, enriquecendo o trabalho, aprimorando e aprendendo a aprender. Dessa forma foi criada uma interação, compartilhando saberes, informações, valores, ideias, trabalhando de forma integrante e colaborativa com toda a equipe escolar.

Le Coadic (2004, p.5) reporta que a sociedade da informação inaugura a era da informação, uma época sustentada por tecnologias que possibilitam trocas de informações multimodais já que - a informação é um "conhecimento inscrito (gravado) sob a forma escrita (impressa ou numérica), oral ou audiovisual”. Já para a Castells (2007), a era da informação é também denominada como era digital devido ao fortalecimento de um movimento de conexão da sociedade em rede no final do século XX.

Esse novo cenário requer conectividade e uma reformulação da atuação do bibliotecário escolar no seu campo de trabalho, de forma que desenvolva outras competências, já que os bibliotecários, como esclarece Gerlin (2020, p. 8), se 
apresentam como mediadores da informação e da leitura - são "agentes responsáveis para garantir um aprendizado contínuo e colaborativo no meio social”.

Os bibliotecários escolares da rede municipal de ensino de Vila Velha trabalham com a premissa de três principais focos: formação do leitor, uso ético da informação, projetos culturais. Dentre os principais projetos vale citar o "Concurso Literário Entre Versos e Rimas e Outras Histórias", que engloba toda a comunidade escolar, onde é trabalhado o projeto com tema especifico e que possui gêneros literários variados como: poesia, memória literária, crônica, desenho, artigo de opinião e click fotográfico.

A academia de letras seleciona os melhores trabalhos que são publicados num livro produzido pela própria secretaria de educação (Semed) e a culminância do evento se dá em grande festa, com apresentação de cantores capixabas, e entrega de livros, medalhas e sorteios de tablets para os premiados. Os livros também ficam disponíveis nas bibliotecas das escolas e na biblioteca pública do município. Outro projeto da PMVV é a visita de escritor, com a participação de autores capixabas.

Assim sendo, o trabalho realizado pelos bibliotecários e professores juntamente com os alunos, trabalhando também a biografia dos escritores para apresentar no dia do evento. São projetos de ação cultural e identidade social, fontes atuantes e enriquecedores no incentivo a leitura e formação educacional dos usuários quanto à habilidade leitora e revelação de talentos.

\section{MATERIAIS E MÉTODOS}

A seguir serão mencionados os procedimentos empregados, ressaltando a ambiência da pesquisa e os procedimentos de coleta de dados:

\section{Procedimentos Metodológicos}

Como procedimentos metodológicos, além das informações teóricas utilizadas, desenvolvemos um questionário aplicado online aos bibliotecários escolares atuantes na rede municipal de ensino, localizada na cidade de Vila Velha, no Estado do Espírito Santo. Assim o presente estudo possui caráter descritivo e qualitativo, utilizando um questionário semiestruturado com a temática: atuação do grupo de bibliotecários de Vila Velha com as questões que envolvem a influência da tecnologia de comunicação digital em época de pandemia, utilizadas para o trabalho em home Office, com auxílio dos colegas de profissão e de toda a comunidade escolar para dar continuidade as atividades de EaD. O reinventar do profissional atuante em meio a pandemia, com a utilização das ferramentas de tecnologias digitais.

Para a coleta de dados utilizou-se um questionário semiestruturado, adaptado no campo da Ciência da Informação. Assim, foram aplicados 31 questionários em plataforma digital (enviados por e-mail e redes sociais) entre os dias 10 a 15 de junho de 2020, para a rede de bibliotecários - atuante na cidade de Vila Velha/ ES.

O questionário abrange um rol de 10 perguntas fechadas e uma aberta, totalizando 11 perguntas. As quatro primeiras perguntas têm como objetivo identificar o público alvo (acerca da faixa etária, gênero, grau de instrução e escola em que atuam). As outras seis questões abordam especificamente, a temática do trabalho; a proposta principal é: i) verificar aspectos da comunicação digital entre o âmbito dos profissionais das bibliotecas escolares num momento de crise sanitária; e ii) analisar se existe afluência nas relações profissionais, quais contornos adquire o campo de trabalho e quais fluências relacionais. 
Nesse sentido, seguindo nos preceitos éticos, e a diretrizes de sigilo dos participantes a apresentação por codinome reafirma nosso compromisso ético de pesquisa. A pesquisa se utilizou de lendas Capixabas e do folclore brasileiro como forma de codinome para resguardar sigilo / identidade dos participantes. Por conseguinte, a pesquisa não segue uma abordagem quantitativa e sequer tem um caminho metodológico voltado a análise do discurso, contudo, são indicações ricas ao se cruzar um enfoque misto de metodologias (ALMEIDA, 2016).

Diante esse quadro avaliativo, se tenta empoderar o público dando voz as suas percepções e expectativas, captando o olhar de quem trabalha para o processo de desenvolvimento de serviços e para quem de fato busca cada vez mais se surpreender. A beleza desse processo é mostrar que o enfoque transformação é algo perene e hodiernamente a coisa social mostra um 'abre alas' para se pensar e reformular a performance.

No ano de 2020, a humanidade tem enfrentado uma das maiores tragédias ocasionadas pela contaminação e proliferação da Covid-19 [...] Essa tragédia sanitária provocou mudanças profundas [..] Nesse contexto de pandemia da Covid-19 e de isolamento social houve uma ampliação no uso das tecnologias digitais, na produção de informações nas redes sociais, na oferta de eventos técnicocientíficos e culturais em diversas mídias sociais. Por outro lado, na contramão, também foi ampliada a produção e disseminação das chamadas "fake news", provocando um estado de desinformação na sociedade, cujas consequências são nefastas ao imaginário e ao comportamento ideológico dos indivíduos. Diante desse cenário, as áreas de Biblioteconomia, Ciência da Informação e afins têm um papel [...] de integrar digital e socialmente os cidadãos, de modo que eles estejam cientes sobre o uso ético da informação e sobre a prevalência da responsabilidade social no momento da sua disseminação. Por outro lado, compreende-se que novos cenários estão surgindo em consequência do acelerado processo de produção da informação e das demandas do mercado, o que exige novas competências e habilidades a serem desenvolvidas nos perfis profissionais dos cursos de Biblioteconomia e Ciência da Informação (REVISTA BIBLIOMAR, 2020, p. 5-6).

Não obstante esperamos que a Covid-19 passe tão longo, como uma lenda que traz aprendizado, conscientização, senso de responsabilidade e humanização, posto que:

2020 será certamente lembrado como um dos anos mais importantes da história humana recente. A pandemia de Covid-19, deflagrada no final de 2019, mas com impacto global no começo de 2020, tem provocado enormes transformações nos costumes, nas sociabilidades, na política e na economia mundial. A pandemia desnuda e realça as fraquezas, os limites e as mazelas de nossos modos de vida e de produção. Expõe as contradições e os crimes do capital, sacrifica a vida dos pobres e compromete o lucro e o luxo dos ricos. No Brasil, suscita conflitos políticos entre as esferas federal, estadual e municipal, aguça a cobiça dos estelionatários de plantão e salienta o valor e os riscos do trabalho de profissionais de saúde, bem como dos trabalhadores autônomos, informais e precarizados (ZANZALÁ, 2020, p. 1).

Com base em seu expansionismo, a pandemia, dentro do ambiente organizacional, transformou os espaços para o compartilhamento de informação e do conhecimento. E assim, a Covid-19 não é algo a ser esquecido jamais, deixou marcas profundas na 
identidade social, efetivou uma renca de mudanças nas relações de trabalho, afetou milhares de famílias de forma ímpar e imemoriável de seus entes queridos.

\section{A Rede de Bibliotecários Escolares de Vila Velha: breve relato da ambiência/atuação}

A cidade de Vila Velha compreende uma Zona Litorânea com aproximadamente 350 mil habitantes e, possui 101 escolas municipais - e todas com biblioteca.

Figura 1- Caracterização do município de Vila Velha.

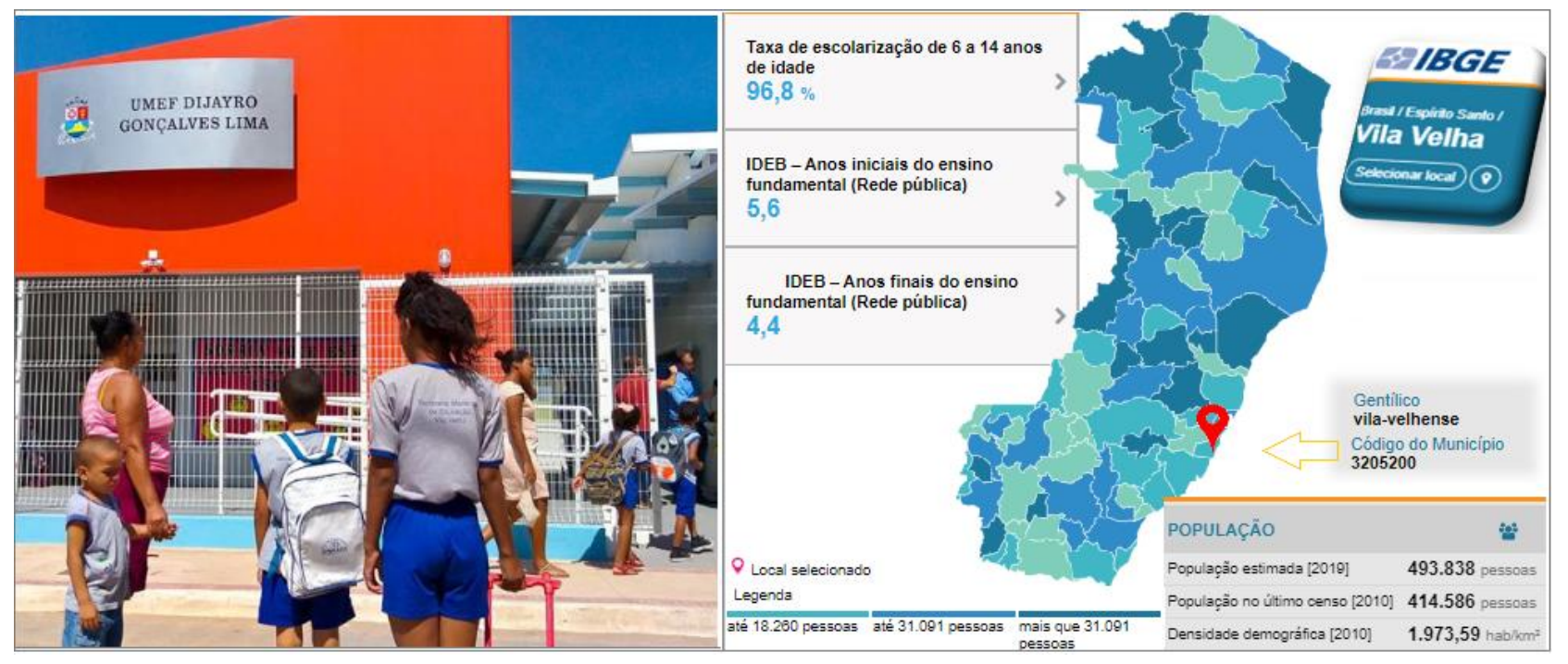

Fonte: Prefeitura de Vila Velha (PMVV) e IBGE cidades (2020).

A rede de ensino municipal possui 38 Unidades Municipais de Educação Infantil (Umeis) e 63 outras Unidades Municipais de Ensino Fundamental (Umefs); cabe ressaltar que, os bibliotecários atuam somente nas Umefs. Destarte, o ensino fundamental abraça diferentes escolas: a) de primeiro ao nono ano; b) primeiro ao quinto; e c) as que têm do sexto ao nono - isto é, o lugar em que atuam " 58 bibliotecários", alguns trabalhando em duas escolas em dias alternados (BARBOSA; PEREIRA, 2020, p. 42).

\section{ANÁLISE E DISCUSSÃO DOS RESULTADOS}

Levando em consideração manifestações do Ministério Público do Espírito Santo (MPES), o Decreto de Emergência em Saúde Pública (Decreto $n^{\circ} 4593-R$ ) do Governo do Estado (ES), além das decisões das instituições federais de ensino, do governo estadual e de outras prefeituras da Região Metropolitana da Grande Vitória (RMGV) de suspenderem suas aulas. Assim, dentre os 58 bibliotecários que atuavam no município de Vila Velha, antes da pandemia, apenas 27 profissionais não puderam ter o contrato renovado - havia três bibliotecários efetivos na Prefeitura Municipal de Vila Velha/ES (PMVV), os demais são contratos que atendem às necessidades temporárias do município.

Dessa forma a pesquisa foi realizada com os 31 bibliotecários atuantes. Dos entrevistados, 22 são mulheres, 8 se declaram homens e 1deles aponta outra 
designação para o gênero; os dados apontam um grupo predominante de mulheres (70,97\%), conforme mostra a ilustração (figura 2) a seguir.

Figura 2 - Características do público alvo

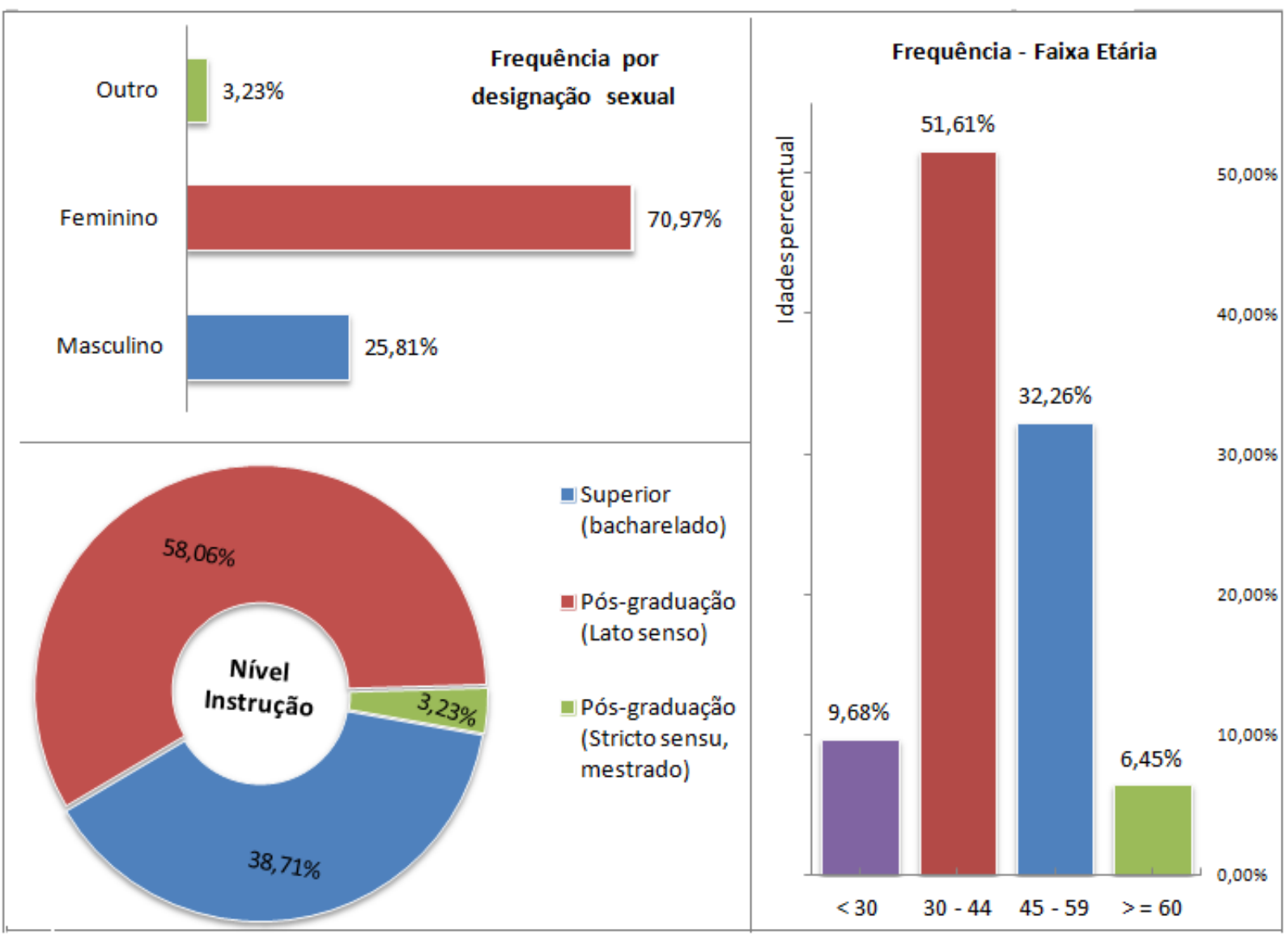

Fonte: Elaborada pelos autores, dados da pesquisa, jun. 2020.

É importante citar que há uma predominância do gênero feminino nas Bibliotecas Escolares da Rede Municipal de Ensino de Vila Velha, em que se aplicou o questionário; isso reflete o cenário de hoje, que apesar das mulheres estarem ganhando visibilidade no mercado de trabalho, ainda existe uma grande lacuna, que parece distante, mas que percebe-se a permanência desse desequilíbrio na sociedade.

Os dados recolhidos mostram que o público predominante da entrevista possui uma faixa etária entre 30 a 44 anos; assim, a média no que tange a idade é de 43 anos, a mediana corresponde a 41 e a moda da série numérica apresenta o indicativo 40 para a idade. Já o grau de instrução dos entrevistados mostra que 58,06\% possuem pósgraduação (lato senso) completa - tal realidade de especialização e capacitações são oportunidades estimuladas pela coordenadora Eliana Terra, da Rede de Bibliotecas escolares das Unidades Municipais de Ensino de Vila Velha- ES.

Na sequência, a ilustração trata dos percentuais sobre equipamentos utilizados para acessar a internet (e comunicar online) e, traz indicativos sobre a frequência de utilização da web; e com esse aporte se verifica que $87,10 \%$ utilizam a internet diariamente (figura 3) e 80,65\% utilizam smartphones como principal equipamento para realizar as tarefas direcionadas aos alunos. 
Figura 3 - Utilização da internet e frequência utilizada

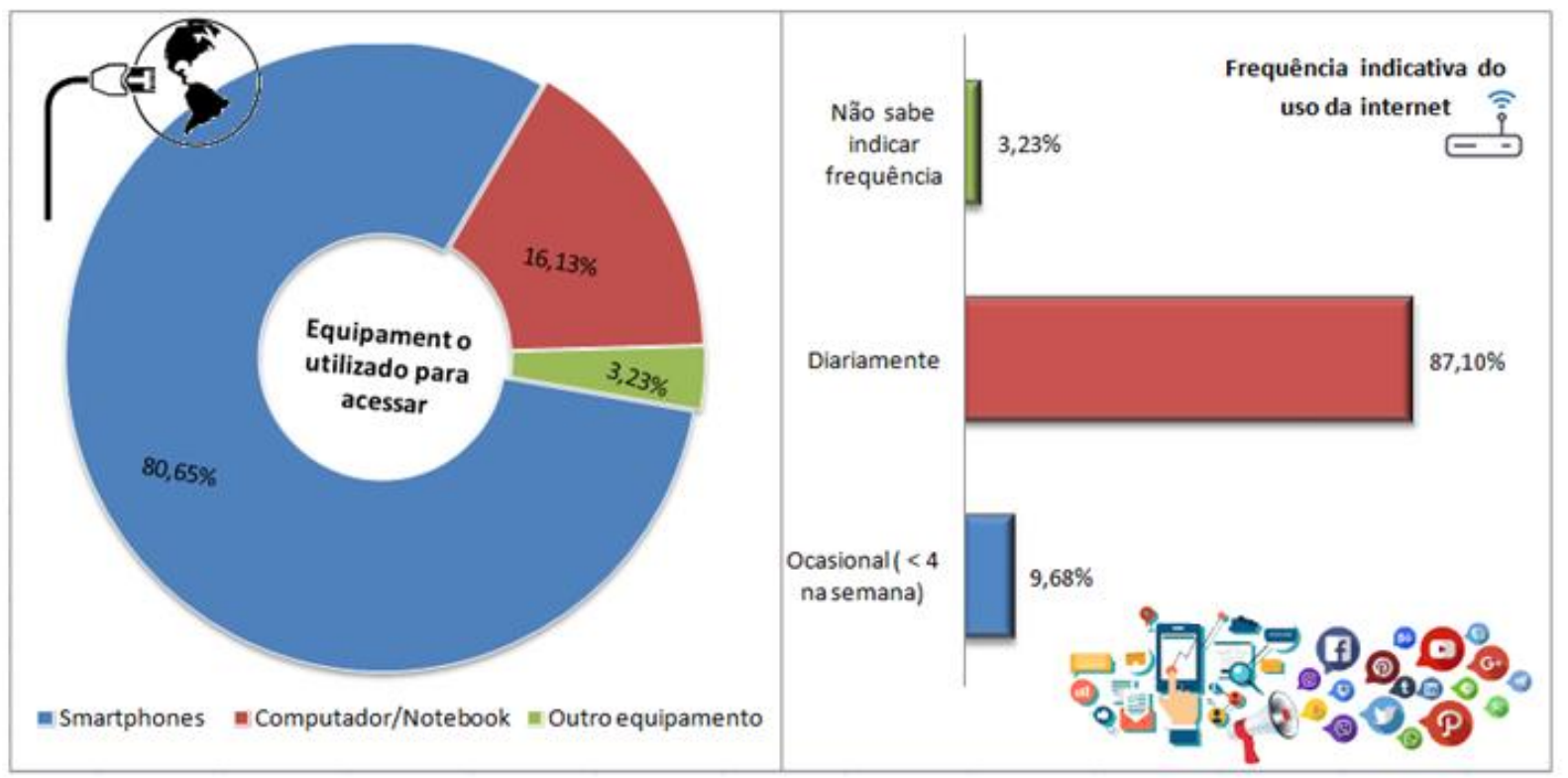

Fonte: elaborada pelos autores, dados da pesquisa, jun. 2020.

Diante esse painel do mundo digital, o estudo ressalta que os telefones inteligentes são os principais instrumentos para agir no meio de comunicação virtual; assim, é notório que os smartphones são representativos quando se pensar em ferramentas imprescindível ao dia a dia dos indivíduos no campo profissional, acadêmico e, sobretudo social.

Figura 4 - Utilização de plataformas web e equipamentos mais utilizados

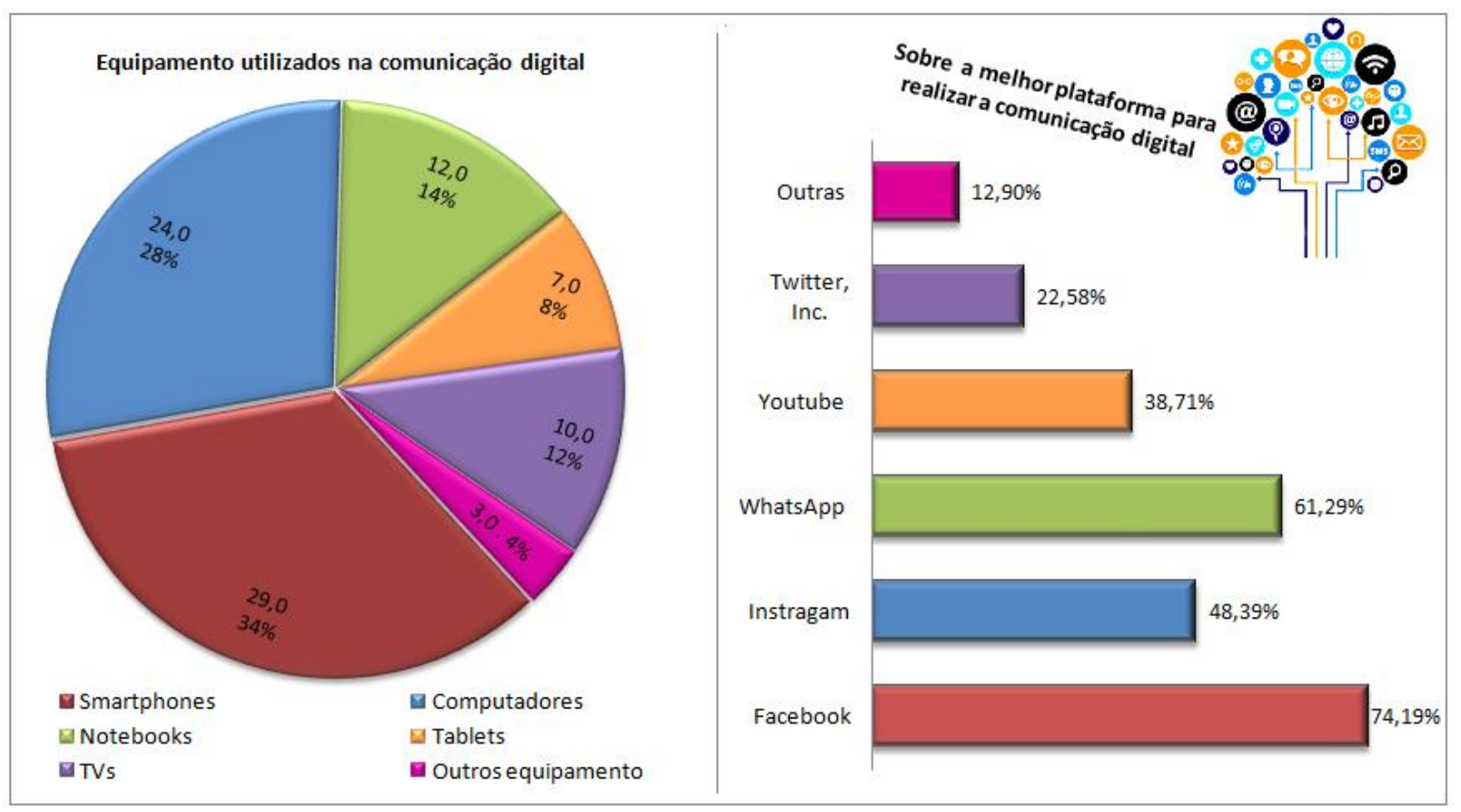

Fonte: elaborada pelos autores, dados da pesquisa, jun. 2020.

Já a investigação em sintonia com o uso da web, mostra que os celulares são os equipamentos mais utilizados a comunicação digital e social - e, o que tange a 
plataforma para se comunicar, se averigua que o Facebook, Instagram, WhatsApp, YouTube's e Channel são os mecanismos que mais pautam o avançar da comunicação digital em conexões domésticas com a internet.

Dessa forma, o estudo ressalta que a rede Facebook expressa (74,19\%), no campo da comunicação, explanando como a plataforma mais usada e indispensável à rotina no âmbito profissional, acadêmico e, principalmente social dos bibliotecários da rede Municipal de Vila Velha -ES.

Perante a face da influência das mídias sociais e a importância da web para atividades da área, o ato de comunicar, para os respondentes expõem que a internet simboliza um status de grande relevância para toda a sociedade da informação, e isso mostra que afeta de forma relevante o campo profissional e as relações de sociabilidade. Assim, se apura que de fato as pessoas estão cada vez mais conectadas, dependentes ou influenciadas pelas mídias digitais - isto é, algo imperativo e nada trivial para o ato de comunicar numa era pandêmica.

A ilustração a seguir (figura 5) traz apontamentos da influência da mídia e a importância da web; se observa com essa pauta que o quantitativo profissional vê, de forma proeminente - extremamente importante para estabelecer comunicação.

Figura 5 - Influência das mídias e a importância da internet

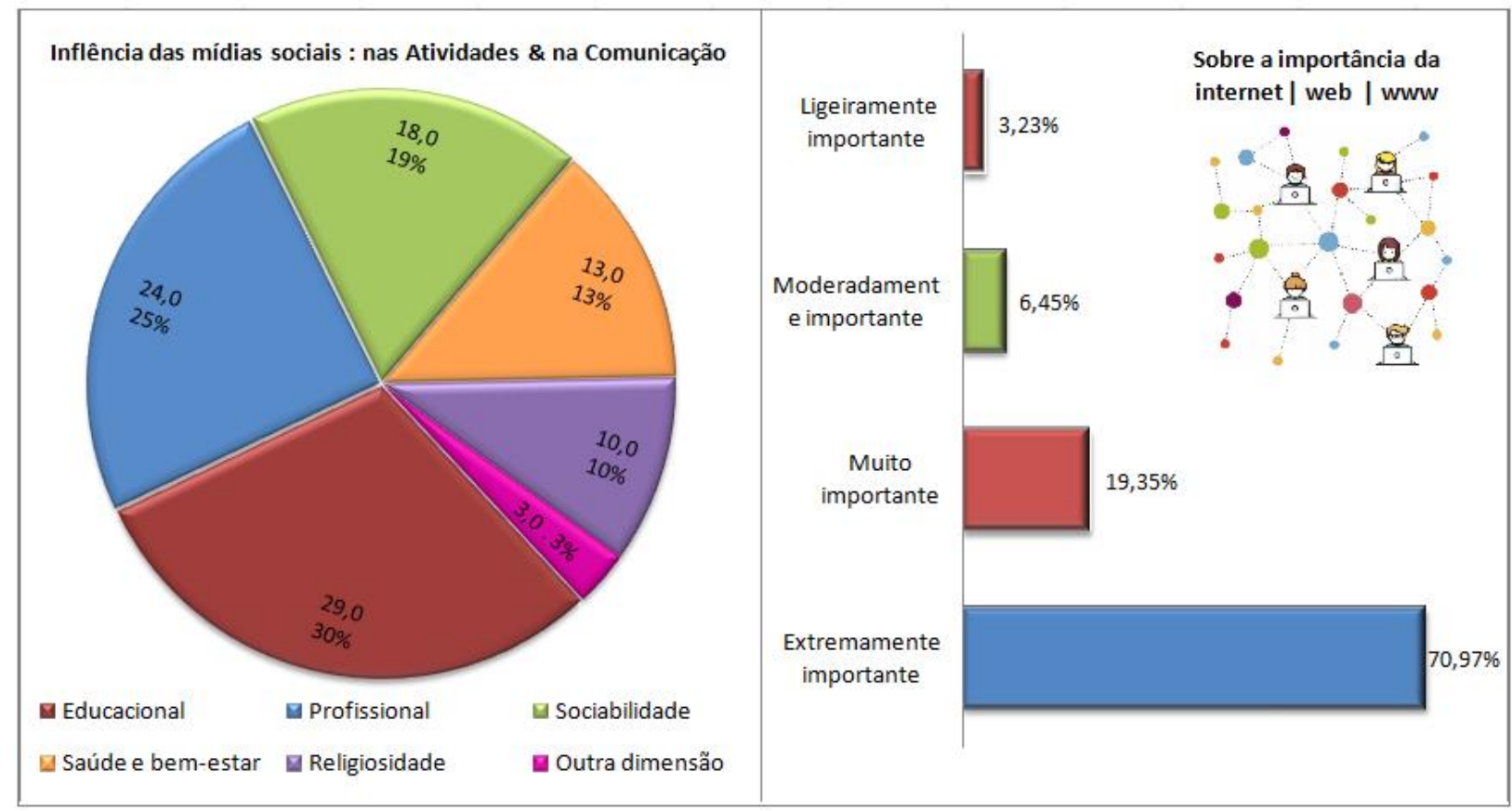

Fonte: elaborada pelos autores, dados da pesquisa - jun.2020.

As perspectivas, desse grupo de bibliotecários, para parâmetros se situam a importância da web e a influência das mídias sociais em atividades e no ato de comunicar relevam que essa afeta principalmente a área educacional e profissional; ratifica que a web tem extrema importância para os bibliotecários.

A influência da internet para a vida do indivíduo retorna a resposta de ser "extremamente importante" para $(70,97 \%)$ desse grupo; e sobre a questão da influência das mídias sociais e digitais para o campo da comunicação, os respondentes declararam que essa esfera afeta o percurso educacional (para 29 participantes), a vida 
profissional (de 24 respondentes) e a vias da sociabilidade (segundo 19 entrevistados) - tais dados podem ser observados na ilustração acima (Figura 5).

Tendo em vista esses dados, percebe-se mais uma vez a importância dos aparelhos Smartphones que, por conta da evolução tecnológica, cada vez mais oferecem um aparelho de fácil acesso, prático, inteligente, pequeno e de fácil locomoção.

\section{Avançar e comunicar em um tempo de crises e mudanças}

A sequência traz à baila três aspectos: i) os vocábulos que definem a comunicação digital; ii) os aspectos que influencia a comunicação digital na sociedade contemporânea; e iii) os assuntos pesquisados na web para estabelecer diálogos.

O estudo questionou ao grupo de bibliotecários da rede municipal de Vila Velha, "quais termos (três palavras)" seriam significativas para definir a "comunicação digital"; assim se resgata nos depoimentos o seguinte painel temático ao utilizarmos a nuvens de palavras (também conhecidas como word clouds ou nuvem de tags) que expressam representações visual de vocábulos que dão maior destaque e que aparecem com mais frequência.

Figura 6 - Termos/vocábulos sugeridos para definir a comunicação digital

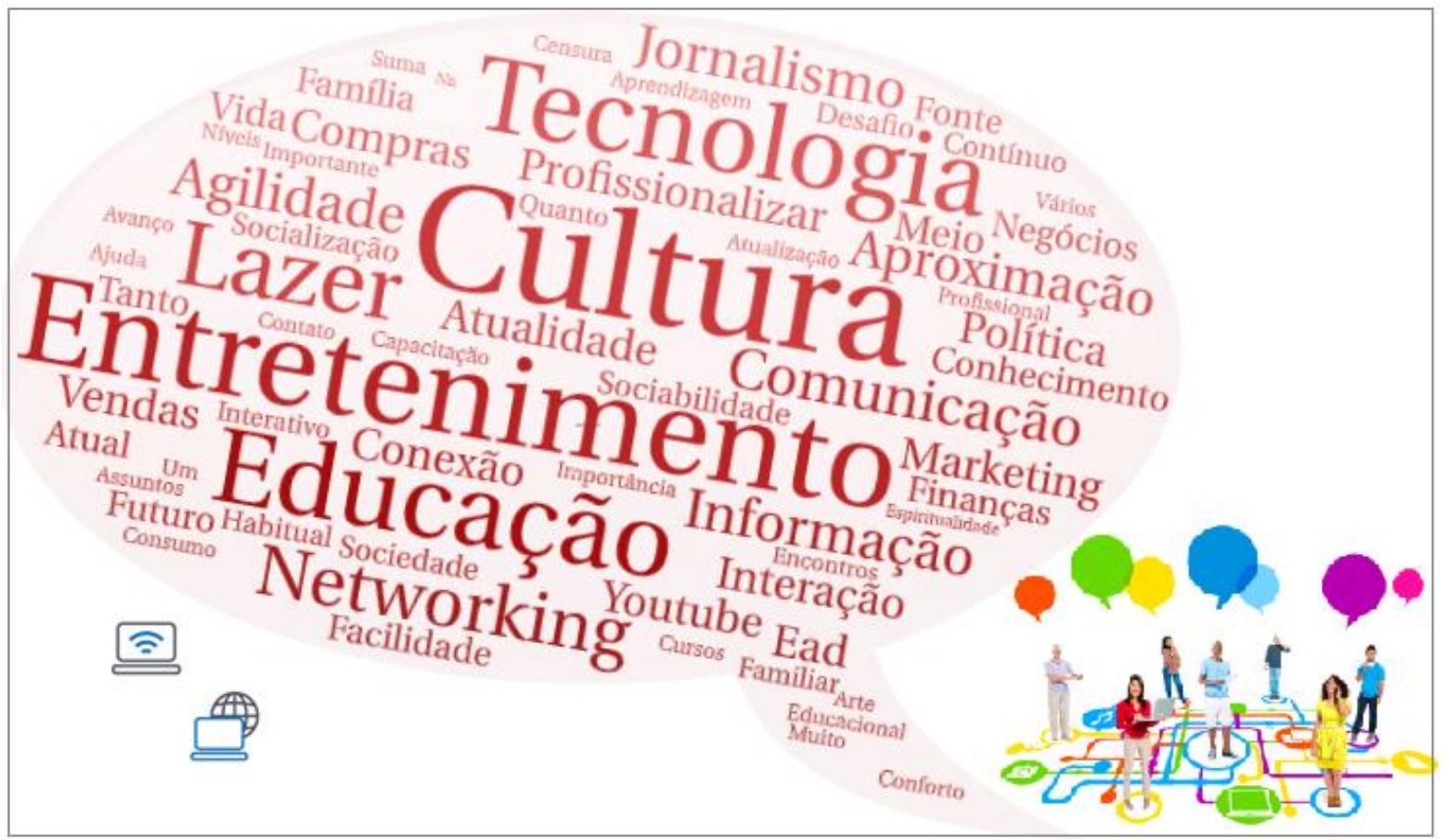

Fonte: elaborado pelos autores, dados da pesquisa, jun. 2020.

Diante das respostas, os participantes rotulam as buscas por assuntos relacionados a educação, cultura, tecnologia e entretenimento. Desse modo, no rol de assuntos que pontua significância para a comunicação, esse grupo de bibliotecários reporta que também a política, os negócios e o jornalismo, são alvos para pesquisar e direcionam pautas para a comunicação.

Acrescenta-se que o bibliotecário deve ir onde o leitor está e também deve se atualizar, expandir, redirecionar, aprender junto. Descobrir o mundo na era digital é estar 
disponível para novos caminhos na construção da aprendizagem para toda comunidade escolar quando e onde quer que o leitor dele precise.

A pesquisa questionou o grau (escala de um a cinco, sendo 5 mais relevante) que alguns aspectos influenciam a comunicação na sociedade hodierna; cada respondente deveria atribuir a pontuação de 0 a 5. Os resultados obtidos estão representados no Quadro 1 a seguir.

Tabela 1 - Aspectos que influenciam a comunicação na sociedade

\begin{tabular}{|c|c|c|c|c|c|c|c|c|c|c|c|c|}
\hline ESCALA & 0 & & 1 & & 2 & & 3 & & 4 & & 5 & \\
\hline $\begin{array}{l}\text { Ambiental \& } \\
\text { biológico }\end{array}$ & & & 3 & $9,7 \%$ & 4 & $12,9 \%$ & 7 & $22,6 \%$ & 8 & $25,8 \%$ & 9 & $29,0 \%$ \\
\hline $\begin{array}{l}\text { Artístico \& } \\
\text { cultural }\end{array}$ & - & - & 2 & $6,5 \%$ & 1 & $3,2 \%$ & 4 & $12,9 \%$ & 13 & $41,9 \%$ & 11 & $35,5 \%$ \\
\hline Cognitivo & 1 & $3,2 \%$ & 1 & $3,2 \%$ & 3 & $9,7 \%$ & 6 & $19,4 \%$ & 7 & $22,6 \%$ & 13 & $41,9 \%$ \\
\hline $\begin{array}{l}\text { Econômico \& } \\
\text { financeiro }\end{array}$ & - & - & 3 & $9,7 \%$ & 2 & $6,5 \%$ & 4 & $12,9 \%$ & 12 & $38,7 \%$ & 10 & $32,3 \%$ \\
\hline Educativo & & & 5 & $16,1 \%$ & 1 & $3,2 \%$ & 2 & $6,5 \%$ & 7 & $22,6 \%$ & 16 & $51,6 \%$ \\
\hline Familiar & - & - & 3 & $9,7 \%$ & 2 & $6,5 \%$ & 5 & $16,1 \%$ & 10 & $32,3 \%$ & 11 & $35,5 \%$ \\
\hline Informativo & & & 1 & $3,2 \%$ & 2 & $6,5 \%$ & 2 & $6,5 \%$ & 9 & $29,0 \%$ & 17 & $54,8 \%$ \\
\hline Político & - & - & 4 & $12,9 \%$ & 5 & $16,1 \%$ & 2 & $6,5 \%$ & 6 & $19,4 \%$ & 14 & $45,2 \%$ \\
\hline Religioso & 3 & $9,7 \%$ & 9 & $29,0 \%$ & 5 & $16,1 \%$ & - & - & 7 & $22,6 \%$ & 7 & $22,6 \%$ \\
\hline Sociabilidade & - & - & 7 & $22,6 \%$ & 3 & $9,7 \%$ & 1 & $3,2 \%$ & 5 & $16,1 \%$ & 15 & $48,4 \%$ \\
\hline
\end{tabular}

Fonte: elaborado pelos autores, com a síntese dos dados da pesquisa, jun. 2020.

Esses resultados mostram que cada aspecto influencia em graus diferentes na vida do indivíduo, e que muito dos termos mostram que a comunicação tem uma relação com a rotina profissional e pessoal.

E por fim, no diagnostico se averigua o campo das pesquisas na web; nesse clima, os respondentes destacam que suas buscas vão ao encontro do ato de comunicar; em suma, as buscas na internet envolvem temas variados (figura 7) aludidos a seguir:

Figura 7 - As buscas e assuntos de interesse na internet

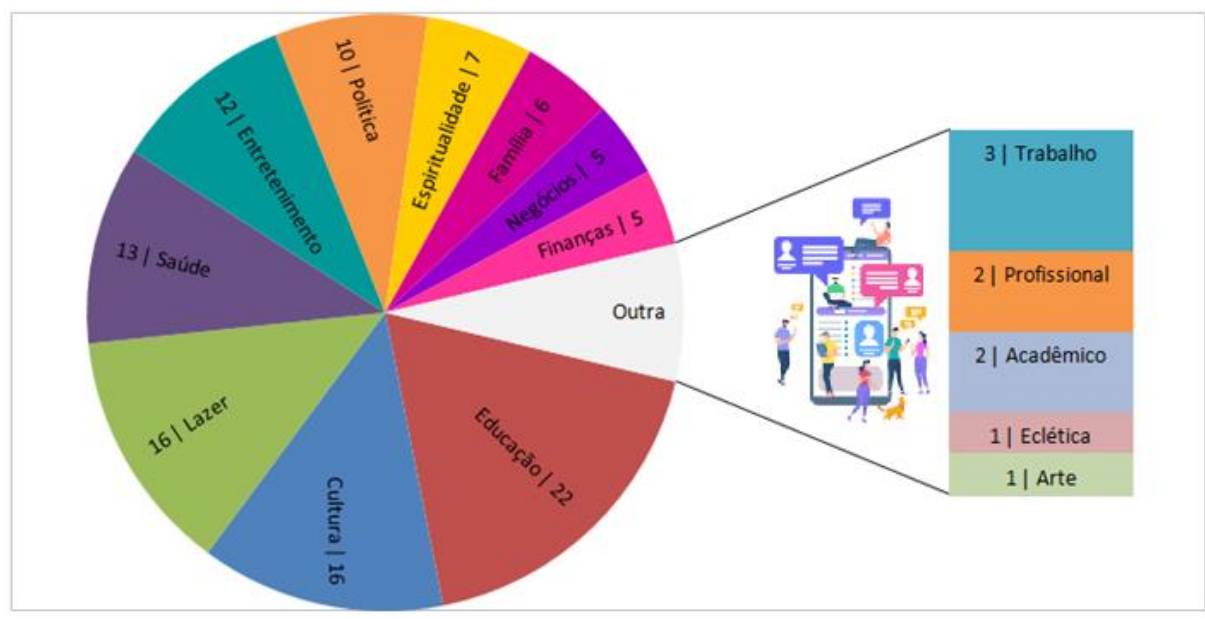

Fonte: elaborada pelos autores, dados da pesquisa, jun. 2020. 
Os resultados da ilustração (figura 7) mostram que a cultura (para 16 entrevistados) e o entretenimento (12 respondentes) são termos pertinentes para expressar a comunicação na era e nos meios digitais; e isto, influencia um rol de construtos, dentre os quais: educação, tecnologia, lazer, networking, jornalismo, política e outras expressões.

Grosso modo, algumas buscas têm ramificações temáticas bem atreladas - aparecem nos relatos diferenciação entre lazer e entretenimento, negócios e finanças, educação e cultura. Nesse panorama, há que se notar que as competências pertinentes ao moderno profissional da informação (MPI) refletem aspectos de: flexibilidade; visão gerencial; coragem para enfrentar riscos; criatividade; liderança; dinamismo; responsabilidade; visão interdisciplinar; atuação interdisciplinar; profissionalismo; ética; conhecimentos sobre organização do conhecimento; visão política na área da informação; uso da informação para o desenvolvimento social e humano; treinamento em recursos informacionais; espírito investigativo; ação investigativa; compromisso com a abertura de novos mercados de trabalho; objetividade e crítica: clareza, precisão e concisão; agilidade mental; motivação interna para desfrutar do trabalho como recompensa pessoal gerando habilidade para a solução de problemas e capacidade de análise (GUIMARÃES, 1997).

\section{A arte de trabalhar em época de pandemia, e nada será como antes}

A questão que tece as considerações a seguir remete ao trabalho em época de pandemia (Covid-19 no Brasil), e com esse painel, os entrevistados apontam algumas mudanças, adaptações, peculiaridades no serviço e as transformações acentuadas no que tange a vida, a solidariedade e a relação de maneira universalística ou holística.

\footnotetext{
O dia 12 de dezembro de 2019 marcou o surgimento de um novo coronavírus, causador de uma epidemia de síndrome respiratória aguda nos seres humanos - doença denominada Covid-19 (do inglês Coronavirus Disease 2019). [...] A atual pandemia de Covid-19 impõe vários desafios [...] Nossa conta de saúde, educação, segurança e cidadania ainda não chegou... Estratégias como home working ou distance schooling não são facilmente traduzidas nesses contextos e demandam soluções rápidas e coordenadas [...] Por outro lado, a Covid-19 proporcionou tempo, ainda que escasso, para a aprendizagem voltada a políticas de enfrentamento da pandemia e suas consequências (RAP, 2020, p.1).
}

Por fim, a word cloud mostra que esses apontamentos influenciam a rotina grupal - a ilustração a seguir (figura 8) destaca os termos que cingem o aglomerado das declarações. 
Figura 8 - Expressões para designar a dimensão do trabalho na pandemia

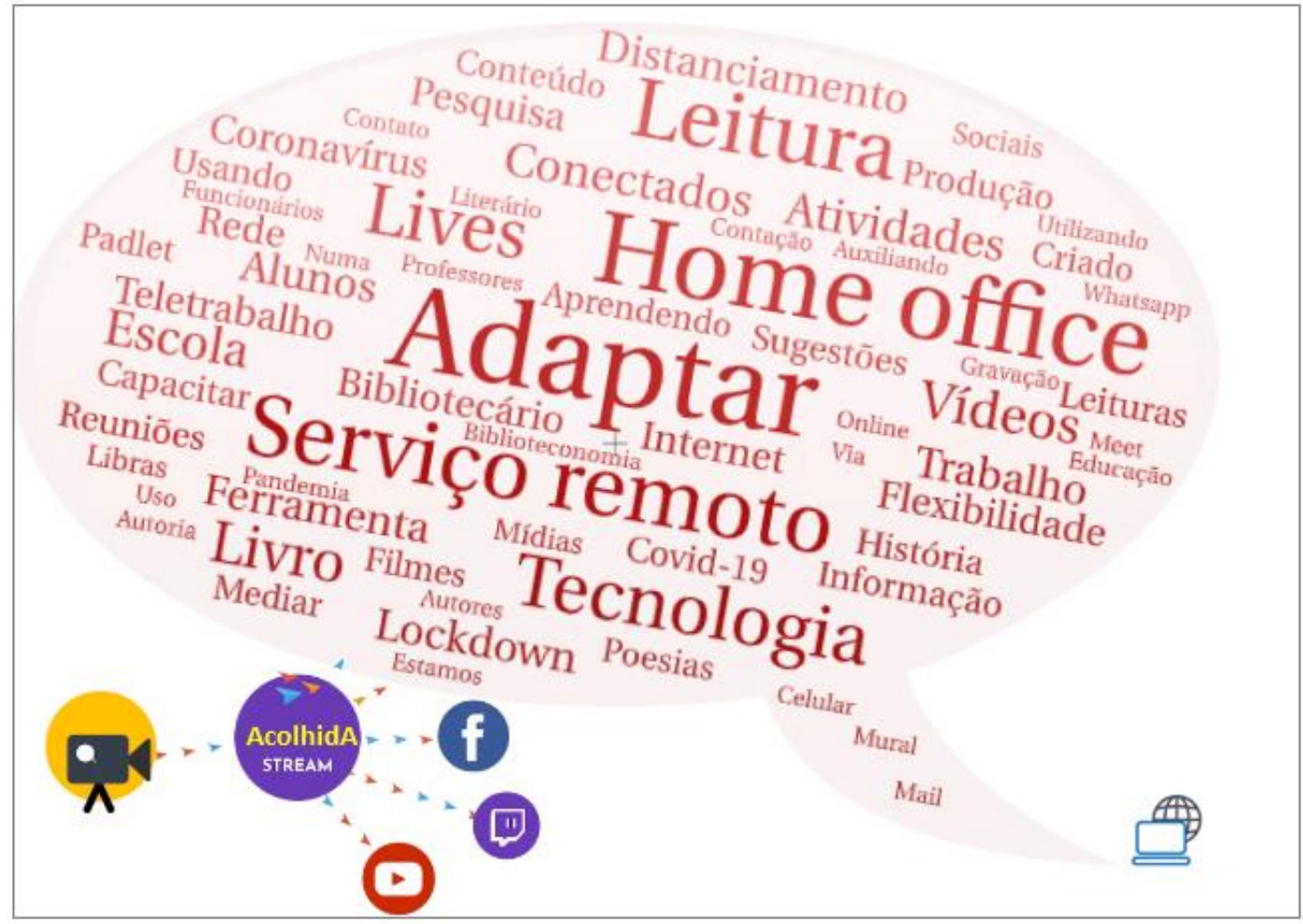

Fonte: elaborado pelos autores, dados da pesquisa, jun. 2020.

Convém destacar que a modernidade vem ligada a tecnologia, mas também aos desafios de se reconstruir como profissional, como líder e protagonista na comunidade escolar. Afinal a biblioteca é, conforme alguns respondentes, o "coração" e a "rocha fundamental" do presente e acolhe uma era desafiadora com o 'coronavírus'; a dimensão social e humanística dessa instituição recebe novas configurações e se fia um novo tecido - o qual é a amplitude o combustível necessário para a abertura de vieses didáticos (sufrágio a informação), o combate a desinformação e o empoderamento de toda a comunidade escolar.

Os respondentes declaram que os trabalhos realizados na pandemia são:

O trabalho em home office e venho auxiliando na alimentação do site conectados da vila e, na divulgação da informação por meio de redes sociais. Busco estimular o incentivo a leitura por meio do site e do mural literário e debate, exposição virtual de livros para o grupo de colegas (COMADRE FULOZINHA - nome fictício - Bibliotecári@, 27 anos).

Vivo em contato direto com outros bibliotecários da rede e com outros funcionários da escola na qual atuo utilizando o whatsapp, o google meet e e-mail. Utilizo meu computador pessoal e acesso à internet na elaboração de conteúdo para disponibilizar aos alunos, bem como para receber colaboração de outros professores, bibliotecários e alunos (IARA - nome fictício - Bibliotecári@, 31 anos).

Tenho criado atividades lúdicas e pedagógicas (cruzadinhas e caçapalavras) para distribuir na escola junto das atividades elaboradas pelos professores, e tenho também pesquisado links com conteúdo 
educativo e enviado como sugestões para ser colocado pela coordenação de bibliotecas no site da PMVV (JACI JETERÊ - nome fictício - Bibliotecári@, 40 anos).

Estou na pandemia trabalhando e muito em home office com a internet, via whatsapp, facebook, e-mail, webconferências, criação de padlets [...] Sou uma pessoa que sabe lidar com tecnologia e busco fazer um serviço remoto de qualidade (BOITATÁ - nome fictício - Bibliotecári@, 43 anos).

A dimensão do trabalho na Covid-19 pauta reuniões em home Office; e estou escrevendo poesias de minha autoria; gravando vídeos e postando nas redes sociais. Encontrei a vontade nata de incentivar o gosto pela leitura, usar o aplicativo Padlet, para que nossos alunos possam conhecer mais dos autores capixabas. Envio atividades educativas relacionadas a leitura e participo de lives, e estou reinventando e aprendendo mais de tecnologias, de forma lúdica e mediadora (SEREIA DE MEAÍPE - nome fictício - Bibliotecári@, 44 anos).

Tenho produzido material de apoio pedagógico, vídeos de contação de histórias, e ainda atuo acompanhado lives, participo de reuniões de trabalho. Tudo digitalmente. Estou me reinventando, eu estou criando conteúdos digitais e aprendendo com as novas tecnologias a adaptar as atividades para os alunos; e aliando tecnologia a formas de criatividade. Colaboro na medida do possível com produção de materiais para compor o projeto e me capacitar na aprendizagem (JOÃO BANANEIRA - nome fictício - Bibliotecári@, 52 anos).

Atuo em home Office, e estou utilizando a internet com o celular e notebook; assistindo lives da minha profissão e fazendo a gravação de vídeos para o YouTube; contação de histórias online e recitação de poesias de minha autoria e de outros autores. Nessa pandemia, o bibliotecário teve que se reinventar e com isso resultou numa maior aprendizagem, interação e conhecimentos com outros profissionais da biblioteconomia e educação (MATINTA-PEREIRA nome fictício - Bibliotecári@, 54 anos).

Os respondentes - bibliotecários com nomes fictícios dos personagens do folclore mostram que as transformações tecidas no trabalho, na comunicação e nas demais relações e interações sociais são uma metamorfose contundente, porém otimiza a visibilidade profissional. O que tange as provocações sobre novas formas de trabalhar a leitura. "Busco-trazer novos materiais para incentivar e promover a leitura, e de forma flexível crio formas para mostrar que o distanciamento provocado pela Covid-19 não é um lockdown para atividade escolar; estamos conectados e adaptando sempre" diz o bibliotecário escolar (GORJALA - nome fictício - Bibliotecári@, 26 anos).

Matinta-Pereira (54 anos), lara (31 anos) e 'João Bananeira' (nome fictício Bibliotecári@, 52 anos) esclarecem que o trabalho do bibliotecário na pandemia envolve a especificidade de "conteúdos e criações" - o teletrabalho ou home office traz um palco criativo ao campo da Ciência da Informação, isto é, uma vasta gama de ferramentas na forma de pensar a mediação (vídeos, padlet, libras, meet, murais, gravações, contação de histórias, publicações) de informações. As projeções desses entrevistados e dos outros, mostra que a rotina mudou e tem que se (re)inventar no campo educacional, e se abrir para novas forma de comunicar: whatsapp, lives, influenciar digitalmente, reunir online, auxiliar os pares, aprender a aprender, expandir 
a atividade da leitura e a importância do livro e da biblioteconomia com recursos remotos da tecnologia para canais digitais (youtube, instragran, google apps, podcasts, blogs).

O “olhar' dos bibliotecários” escolares, diz ‘Caipora' (nome fictício - Bibliotecári@, 31 anos), pontualmente é "solidário e acolhedor, temos uma missão comunicativa e humanitária que pauta a diversidade, cultivos e atos para a sociabilidade". A biblioteca escolar, no decorrer desse trabalho, é apresentada como um instrumento fundamental de apoio às atividades pedagógicas e o trabalho do bibliotecário envolve a mediação com criatividade, imaginação e reflexão que o moderno profissional da informação deve ter (MPI) conforme estudos de Santos (1996); Guimarães (1997); Beraquet et al. (1999); Valentim (2000); Arruda, Marteleto e Souza (2000); e de Silveira (2008).

\section{COMENTÁRIOS FINAIS}

É preciso casar João, é preciso suportar Antônio, / é preciso odiar Melquíades, é preciso substituir nós todos / É preciso salvar o país, é preciso crer em Deus, / é preciso pagar as dívidas, é preciso comprar um rádio, é preciso esquecer fulana. / É preciso estudar volapuque, é preciso estar sempre bêbado, é preciso ler Baudelaire, / é preciso colher as flores de que rezam velhos autores. / É preciso viver com os homens, é preciso não assassiná-los / é preciso ter mãos pálidas e anunciar o Fim do Mundo (ANDRADE, C. D., 1980. p. 47).

As coisas inópias do tempo mostram que "existe o medo" e "é preciso salvar o país" e que há contas a pagar. Já nas lendas capixabas (pássaro de fogo; frade e a freira) desponta uma dimensão alegórica para o distanciamento, e alude que os seres se tornam rochedos e se tornam um 'memorial numerável'. E dessa forma, a pesquisa apresentada apresenta certas tradições e o real adaptar, ambos indissociáveis a vida; e, além de algoritmos se têm o ser humano em pauta. A obra de Andrade (1980), por exemplo, traz um tempero especial para se pensar o 'novo normal' em recontextualizações poéticas, como exemplos: - E agora, José?; No meio do caminho tinha uma pedra; Poema da necessidade; Conferência do medo; Sentimento do Mundo.

Em síntese, esta pesquisa teve como objetivo compreender o impacto da internet na vida pessoal da sociedade desde a forma de comunicação até a mudança de comportamento, e mostra que a pandemia, embora seja uma experiência dramática, abriu novos horizontes, para a inovação, tecnologias, criatividades. A partir dessa temática, surgiram os objetivos específicos: identificar por meio da biblioteca escolar as formas de comunicação existentes na era digital (era da informação e do conhecimento), e elucidar que as redes sociais exerceram fundamental relevância num período de transformações sanitárias no planeta.

O estudo levantou informações teóricas e práticas para adentrar na infoera, e assim se perceber sutis mudanças na comunicação e as transformações que ocorrem na sociedade provocada pela rede - interações sociais e profissionais. Além disso, a pesquisa tece a importância da capacitação dos colaboradores e a modernização da rede de educação, fator essencial para que a escola acompanhe a evolução tecnológica.

A complexidade da infoera e as particularidades da quarentena e isolamento domiciliar traz novas exigências profissionais, bem como as necessidades e expectativas comunicacionais urgênciam o delineamento de um novo projeto pedagógico no 
âmbito da biblioteconomia. Para o atendimento a este novo cenário, os modernos profissionais da informação precisam analisar sua missão, sua competência e seus próprios valores éticos.

Partindo do pressuposto que toda inovação é difícil de ser aplicada, geram desafios e organização, os bibliotecários da rede municipal de Vila Velha estão se reinventando/ressignificando o trabalho home Office à medida que o conteúdo se tornou acessível online, mais direcionados a conectar leitores e construir conhecimentos, nesse momento de mudanças radicais principalmente para os profissionais da informação no âmbito educacional.

Algumas recomendações que podem ser feitas na interface dessa temática e o período da pandemia incluem:

- A criação de incentivos para atrair clientela e formação profissional necessária para atuar na infoera;

- A diversificação e o estreitar de contatos/vínculos com instituições formadoras e empregadoras de profissionais bibliotecários na região;

- O direcionar das ações, investir na capacitação e treinamento do corpo profissional;

- O (re)criar e fortalecer de vínculos profissionais com seus ex-alunos de forma a tê-los como participantes em seus processos permanentes de visibilidade;

- A criação de vários projetos avaliativos permanentes, por exemplo, ocorreu a adaptação de um projeto paralelo pela coordenação de bibliotecas, intitulado 'Vozes que Encantam', onde qualquer aluno, pais, bibliotecários e professores gravam vídeos, contam histórias utilizando instrumentos musicais recitam poesias de sua autoria ou de outros autores, ensinam oficinas diversas, para postar no canal Youtube da biblioteca ou na página do Facebook, intitulado 'bibliotecas escolares pmvv'.

- No período da pandemia foi construído o site "Conectados da Vila" pela equipe da Secretaria Municipal de Educação (Semed), onde (segundas feiras) são postadas atividades da comunidade escolar relacionado para alunos da educação infantil a Educação para Jovens e Adultos (EJA).

Considera-se que a sociedade 'mudou' e continua mudando no decorrer dos anos e, a cada surgimento de novas tecnologias e com o avanço do Covid-19, surgem novos impactos e agentes causando adaptações na vida de cada indivíduo. A comunicação digital é a fonte de informação que vem se tornando cada vez mais notória para o grupo de bibliotecários escolares no período da pandemia.

Os modernos profissionais da informação utilizam tal recurso, reconhecem esta mudança de comportamento e se prepararam não só para interagir com a comunidade escolar, mas também surgem novos websites com informações confiáveis que auxiliam a construção de múltiplas perspectivas profissionais. Isso mostra que o bibliotecário é um profissional ativo e assim, não só usufrui, mas, contribui para os avanços de cidadania, comunicação, educação, informação, aprendizagem, inovação e tecnologia.

O importante no cenário atual - ou no novo normal - é se adequar aos novos mecanismos da inteligência coletiva. Nessa via, a sociedade cria ferramentas para própria utilização e, por conseguinte, as mesmas dinamizam a vida. Também faz se importante destacar que os bibliotecários devem participar (e cada vez mais) ativamente no desenvolvimento de plataformas digitais (websites, lives, apps, games) 
que auxiliem o processo de comunicação, educação e tecnologias - tendo por base as necessidades e perspectivas de seus usuários, os princípios de qualidade bem como as possibilidades de interação oferecidas pela internet 3.0 ou 'A Web Inteligente'.

\section{REFERÊNCIAS}

AGUIAR, Niliane Cunha de. Organização da informação em bibliotecas escolares: contribuição para a competência informacional infantil. Biblioteca Escolar em Revista, Ribeirão Preto, v. 1, n. 2, p. 31-41, 2012. Disponível em:

http://www.revistas.usp.br/berev/article/view/10652. Acesso em: 13 out. 2020.

ALMEIDA, Nara Gabriela Nascimento de. A importância da metodologia científica através do projeto de pesquisa para a construção da monografia. Folha de Rosto, v. 2, n. 1, p. 57-66, 30 jun. 2016. Disponível em:

https://periodicos.ufca.edu.br/ojs/index.php/folhaderosto/article/view/92. Acesso em: 27-jun.-2020.

ANDRADE, Carlos Drummond de. Antologia poética. 13. ed. Rio de Janeiro: J. Olympio, 1979.

ANDRADE, Carlos Drummond de. Reunião: 10 livros de poesia. 10. ed. Rio de Janeiro: J. Olympio, 1980.

ARRUDA, Maria da Conceição Calmon; MARTELETO, Regina Maria; SOUZA, Donaldo Bello de. Educação, trabalho e o delineamento de novos perfis profissionais: o bibliotecário em questão. Ciência da Informação, v. 29, n. 3, p. 14-24, dez. 2000. Disponível em: https://revista.ibict.br/ciinf/article/view/869. Acesso em: 27 jun. 2020.

BARBOSA, Eliana Terra; PEREIRA, Gleice. Redes de bibliotecas escolares brasileiras: contribuições no processo educativo. Páginas A\&B, Arquivos e Bibliotecas (Portugal), n. Especial, p. 34-45, 2020. Disponível em:

http://hdl.handle.net/20.500.11959/brapci/140533. Acesso em: 28 jun. 2020.

BARRETO, Aldo de Albuquerque. Mudança estrutural no fluxo do conhecimento: a comunicação eletrônica. Ciência da Informação, v. 27, n. 2, 1998. Disponível em: https://revista.ibict.br/ciinf/article/view/869. Acesso em: 27 jun. 2020.

BEDIN, Jéssica; CHAGAS, Magda Teixeira; SENA, Priscila Machado Borges. Competência informacional em biblioteca escolar: ações para o desenvolvimento. Revista ACB, v. 20, n. 3, p. 363-372, set./dez. 2016. Disponível em: http://revista.acbsc.org.br/racb/article/view/1105. Acesso em: 13 out. 2020.

BERAQUET, Vera Silvia Marão; CIOL, Renata; SANTOS, Maria Lygia Kopke; STEFANI, Regina Célia. Qualidade de ensino na Fabi-Campinas face ao moderno profissional da informação. Transinformação, Campinas, v.11, n.1, p. 63-69, 1999. Disponível em: https://brapci.inf.br/index.php/article/download/14970. Acesso em: 27 jun. 2020.

BERLO, David Kenneth. O processo da comunicação: introdução a teoria e a prática. 5 . ed. - São Paulo: Martins Fontes, 1985.

CARVALHO, Sandra Maria Souza de; MIGUEL, Marcelo Calderari; COSTA, Rosa da Penha Ferreira da. Nativos digitais e novas concepções para bibliotecas escolares: o 
bibliotecário como mediador da informação. Revista Brasileira de Biblioteconomia e Documentação, São Paulo, v. 16, p. 1-18, ago. 2020. Disponível em:

https://rbbd.febab.org.br/rbbd/article/view/1385/1220. Acesso em: 21 out. 2020.

CASTELLS, Manuel. A galáxia internet: reflexões sobre internet, negócios e sociedade. Lisboa: Fundação Calouste Gulbenkian, 2004. 325 p.

CASTELLS, Manuel. A sociedade em rede. 10. ed., São Paulo: Paz e Terra, 2007. 698 p.

CASTRO, Jetur Lima de; SILVA, Luiz Eduardo Ferreira da; OLIVEIRA, Alessandra Nunes de. A importância da mediação comunicativa da informação na prática bibliotecária. Em Questão, v. 26, n. 2, p. 286-305, 2020. Disponível em:

https://brapci.inf.br/index.php/res/v/139413. Acesso em: 29 jun. 2020.

CHAGAS, Magda Teixeira. Novos rumos da biblioteca escolar. Florianópolis: CIN/CED/UFSC, 2009.

D'AVILA, Fernanda; FACHIN, Gleisy R. B. O lúdico literário nas bibliotecas escolares. In: BLATTMANN, Úrsula; VIANNA, William Barbosa (org.). Inovação em escolas com bibliotecas. Florianópolis: Dois Por Quatro, 2016, 284 p.

FREIRE, Otávio Bandeira de Lamônica. Comunicação, cultura e organização: um olhar antropológico sobre os modos de comunicação administrativa na perspectiva da comunicação integrada. 2009. Tese (Doutorado em Interfaces Sociais da Comunicação) - Escola de Comunicações e Artes, Universidade de São Paulo, São Paulo, 2009. Disponível em: https://www.teses.usp.br/teses/disponiveis/27/27154/tde14092009-175025/publico/tese_otavio_freire_2009.pdf. Acesso em: 27 jun. 2020.

FUSATTOF, Melissa Pedroso; SILVA, Márcia Regina. As bibliotecas infantis e os bibliotecários: afinando competências. Biblioteca Escolar em Revista, Ribeirão Preto, v. 3, n. 1, p. 51-72, 2014. Disponível em:http://revistas.ffclrp.usp.br/BEREV/article/viewFile/34o/pdf. Acesso em: 12 out. 2020.

GERLIN, Meri Nadia Marques. Biblioterapia e literatura oral: leituras terapêuticas em espaços de informação, educação e cultura. Biblionline, v.15, n. 3, 2019. Disponível em: https://periodicos.ufpb.br/ojs2/index.php/biblio/article/view/45976. Acesso em: 26 jun. 2020.

GERLIN, Meri Nadia Marques. Entre a teoria e a prática: a constituição de uma rede de formação das competências em leitura e em informação. RICI Revista Ibero-Americana de Ciência da Informação, v.13, n. 2, 2020. Disponível em:

http://periodicos.unb.br/ojs311/index.php/RICl. Acesso em: 26 jun. 2020.

GUIMARÃES, José Augusto Chaves. Moderno profissional da informação: elementos para sua formação no Brasil. Transinformação, Campinas, n. 1, v. 9, 1997. Disponível em: https://brapci.inf.br/index.php/res/v/21356. Acesso em: 27-jun.-2020.

HABERMAS, Jürgen. Teoria do agir comunicativo. São Paulo, SP: WMF Martins Fontes, 2012.

KANAN, Lilia Aparecida; ARRUDA, Marina Patrício de. A organização do trabalho na era digital. Estudos Psicológicos, Campinas, v. 30, n. 4, p. 583-591, dezembro de 2013. 
Disponível em: https://www.scielo.br/pdf/estpsi/v3on4/11.pdf. Acesso em: 27 jun. 2020.

KUHLTHAU, Carol. O papel da biblioteca escolar no processo de aprendizagem. In: VIANNA, Márcia Milton; CAMPELLO, Bernadete ; MOURA, V. H. V. Biblioteca escolar: espaço de ação pedagógica. Belo Horizonte: EB/UFMG, p. 9-14, 1999. Disponível em: http://gebe.eci.ufmg.br/downloads/103.pdf. Acesso em: 13 out. 2020.

LE COADIC, Yves-François. A Ciência da Informação. Brasília: Briquet de Lemos, 2004.

LÉVY, Pierre. A inteligência coletiva: por uma antropologia do ciberespaço. 2. ed. São Paulo: Loyola, 1999. 212p.

MIGUEL, Marcelo Calderari; CARVALHO, Sandra Maria Souza de. Biblioteca escolar, nativos digitais e vínculos presentes: memória, modos existir e avançar. In: CONGRESSO BRASILEIRO DE BIBLIOTECONOMIA E DOCUMENTAÇÃO, 28., 2019, Vitória. Anais eletrônicos... Vitória, 2019. Disponível em: https://portal.febab.org.br/anais/article/view/2226. Acesso em: 21 out. 2020.

MILL, Daniel (org.). Dicionário crítico de educação e tecnologias e de educação a distância. Campinas, São Paulo: Papirus, 2018, 736 p.

MORO, Eliane Lourdes da Silva; ESTABEL, Lizandra Brasil. Bibliotecas escolares: uma trajetória de luta, de paixão e de construção de cidadania. In: MORO, Eliane Lourdes da Silva et al. (org.). Biblioteca escolar: presente. Porto Alegre: Evangraf, 2011. p. 13-70.

PORTO, Tania Maria Esperon. As tecnologias de comunicação e informação na escola: relações possíveis... relações construídas. Revista Brasileira de Educação, Rio de Janeiro, v. 11, n. 31, p. 43-57, abr. 2006. Disponível em: https://doi.org/10.1590/S141324782006000100005. Acesso em: 27 jun. 2020.

REVISTA BIBLIOMAR. Editorial. Revista Bibliomar, v. 19, n. 1, jan./jun. 2020. Disponível em:http://www.periodicoseletronicos.ufma.br/index.php/bibliomar/article/view/14453 /7715. Acesso em: 30 jun. 2020.

REVISTA DE ADMINISTRAÇÃO PÚBLICA - RAP. Chamada especial de artigos II: a resposta da administração pública brasileira aos desafios da pandemia. RAP, Rio de Janeiro: Fundação Getulio Vargas: Escola Brasileira de Administração Pública e de Empresas: EBAPE, 1967-., 2020. Disponível em:

http://bibliotecadigital.fgv.br/ojs/index.php/rap/pages/view/chamadaespecialdeartigo s. Acesso em: 27 jun. 2020.

SANTANA FILHO, Severino Farias de. O papel da biblioteca escolar na formação do leitor. In: CONGRESSO DA LEITURA DO BRASIL, 2005, Campinas. Anais eletrônicos... Campinas: UNICAMP, 2005. Disponível em: http://alb.com.br/arquivo-

morto/ediçoes_anteriores/anais15/alfabética/FilhoSeverinoFariasdeSantana.htm. Acesso em: 11 out. 2020.

SANTOS, Jussara Pereira. O moderno profissional da informação: o bibliotecário e seu perfil face aos novos tempos. Informação \& Informação, Londrina, v. 1, n. 1, p. 5-13, jul. 1996. Disponível em: http://dx.doi.org/10.5433/1981-8920.1996v1n1p5. Acesso em: 27 jun. 2020. 
SILVA, Rogério Oliveira da; FELIX, Yara Emmanuelle Fonseca. Uma visão sobre o que vem a ser mundo na era digital. Tecnologias em Projeção, Brasília, v. 1, n. 7, 2016. Disponível em:

http://revista.faculdadeprojecao.edu.br/index.php/Projecao4/article/view/603/584.

Acesso em: 27 jun. 2020.

SILVEIRA, Fabrício José Nascimento. O bibliotecário como agente histórico: do 'humanista' ao 'moderno profissional da informação'. Informação \& Sociedade: Estudos, João Pessoa, v. 18, n. 3, 2008. Disponível em:

https://brapci.inf.br/index.php/res/v/92971. Acesso em: 27 jun. 2020.

SIQUEIRA, Carol. Projeto adia para 2022 prazo para toda escola ter uma biblioteca. Set. 2020. Disponível em: http://www.camara.leg..br/noticias/692. Acesso em: 21 out. 2020.

SOUZA, Rafael Bellan Rodrigues de. A comunicação contra-hegemônica no capitalismo digital: limites e contradições. Liinc em Revista, v. 16, n. 1, 2020. Disponível em: https://doi.org/10.18617/liinc.v16i1.5133. Acesso em: 25 out. 2020.

TOMAÉL, Maria Inês. Redes sociais, conhecimento e inovação localizada. Informação \& Informação, Londrina, v. 12, n. 1, p. 63-86, dez. 2007. Disponível em: http://dx.doi.org/10.5433/1981-8920.2007v12n1espp63. Acesso em: 26 jun. 2020.

TOMAÉL, Maria Inês; ALCARÁ, Adriana Rosecler; DI CHIARA, Ivone Guerreiro. Das redes sociais à inovação. Ciência da Informação, Brasília, v. 34, n. 2, p. 93-104, ago. 2005. Disponível em: Disponível em: http://revista.faculdadeprojecao.edu.br/index.php/Projecao4/article/view/603/584. Acesso em: 27 jun. 2020.

VALENTIM, Marta Lígia Pomim. O moderno profissional da informação: formação e perspectiva profissional. Encontros Bibli, v. 5, n. 9, p. 16-28, 2000. Disponível em: https://brapci.inf.br/index.php/res/v/34299. Acesso em: 27 jun. 2020.

VIEIRA, Vivian Patrícia Peron. Os efeitos da comunicação digital na dinâmica do ativismo transnacional contemporâneo: um estudo sobre a Al-Qaeda, Wikileaks e Primavera Árabe. 2016. 378 f. Tese. (Doutorado em Relações Internacionais) Universidade de Brasília, 2016. Disponível em: https://repositorio.unb.br/handle/10482/20904?mode=simple. Acesso em: 27 jun. 2020.

ZANZALÁ [Revista Brasileira de Estudos de Ficção Científica]. Notícias / Imaginários contagiantes: fantasia, horror e ficção científica na era da Covid-19 Juiz de Fora: Universidade Federal de Juiz de Fora, 2020. Disponível em: https://periodicos.ufff.br/index.php/zanzala/announcement/view/421. Acesso em: 30 jul. 2020. 